\title{
Effect of Silica fume on Ordinary Portland Cement and Polymer Concrete Made out of M Sand
}

\author{
Premkumar R, Ramesh Babu Chokkalingam, M Shanmugasundaram, S.Rajesh
}

\begin{abstract}
In this investigation, conventional concrete was made with replacing the sand by $80 \%$ of $M$-sand and the cement by fillet material silica fume in varying percentages say $5 \%, 10 \%$, and $15 \%$, to study the compressive strength, split tensile strength and flexural strength. In order to the maximum strength was attained at $10 \%$ of silica fume. The result showed that by increasing the silica fume content, the strength of the M-sand concrete was decreased because higher fineness of silica fume content decreases the strength of the M-sand concrete. Secondly polymer concrete with unsaturated polyester resin with hardener MEKP, Cobalt as the accelerator and silica fume in varying percentages say $0 \%, 5 \%$ and $10 \%$ was made to study the compressive strength and split tensile strength of polymer concrete. In improved silica fume content the strength was high. Polymer concrete improved the mechanical properties. Polymer concrete system was mainly useful to fill the micro voids. In this research, the maximum strength was attained at 5\% of silica fume filler added with polymer concrete. Thus the high strength of the concrete was obtained due to the pozzolanic reaction with the silica fume.
\end{abstract}

Keywords : M Sand, , Polymer Concrete, Polyester resin, Silica fume.

\section{INTRODUCTION}

$\mathrm{T}$ he most commonly used fine aggregate for the concrete and mortar production was the river sand but it possess the problem of sensitive shortage and dreadful conditions problems in many areas. In the meantime expanding amount of dust stone residue is accessible from smashers as waste. The exchange of this is a certifiable environmental issue. In the event that it is conceivable to utilize this M-sand remains in making cement concrete and mortar by partially or fully replacement of regular fine aggregate. Numerous scientists examined concrete with incomplete substitution of bond by silica fume up to 20\%[1]. Praveen Kumar, Radhakrishna [2] exhibited that the homogeneity properties of bond mortar

Revised Manuscript Received on December 30, 2019.

* Correspondence Author

Premkumar R*, School of Environmental and Construction Technology, Department of Civil Engineering, Kalasalingam Academy of Research and Education, Krishnan Koil, Tamil Nadu, India. Email: prem.ce@gmail.com

Ramesh Babu Chokkalingam, School of Environmental and Construction Technology, Department of Civil Engineering, Kalasalingam Academy of Research and Education, Krishnan Koil, Tamil Nadu, India.

M Shanmugasundaram, School of Mechanical and Building Sciences, Vellore Institute of Technology, Chennai, Tamil Nadu, India

S.Rajesh, School of Environmental and Construction Technology, Department of Civil Engineering, Kalasalingam Academy of Research and Education, Krishnan Koil, Tamil Nadu, India increments with substitutions of $\mathrm{M}$ sand up to $80 \%$ and decline the properties of completely substitution. The quality in quality properties of M-sand mortar is high when levels diverged from waterway sand solid mortar at all substitution. Since handiness of completely substitution of M sand solid mortar is decrease the homogeneity, anyway quality is more, usage of admixtures [3] can be made to achieve usefulness in standard with trademark sand bond mortar. The including of mineral admixture like fly fiery debris and silica smolder in cement improve the great execution of mechanical (compressive strength, split rigidity, flexural) and durability properties of cement [4]. Polymer solid composites are materials that are picked up by somewhat or entire substitution of the bond spread blended with water in standard mortar and cement with polymer besides, fortify concrete based stretch with polymer. Victor Y.Garas and C.Vipulanandan [5] reviewed polyester polymer concrete composite which have a one of a kind mix of properties that rely on the plan. It demonstrates that variety in parts blend of polyester polymer concrete was one of the elements influencing the properties polymer concrete. The impact of sap content, totals, filaments and coupling operators were basically inspected [6]. It was found that the perfect polymer solid esteem differed from $12 \%-14 \%$.

In this study, The effects of the quantity of filler material silica fume used in the normal production of concrete and polymer concrete and the effects of replacing silica fume used as filler with $\mathrm{M}$ sand in different proportions on the hardened concrete properties were examined. In this study, tests were separated into two principle gathering. In the first group experiments, investigation between silica fume and strength, normal Ordinary Portland Concrete was added in the ratio of $5 \%, 10 \%$ and $15 \%$ and its compressive strength, split tensile and flexural strength were studied. In the second group experiments polymer concrete was produced with resin and various percentage of silica fume $5 \%, 10 \%, 15 \%$ and to study the mechanical properties of polymer concrete.

\section{EXPERIMENTAL PROGRAM}

\section{A. Binding Material}

The cement was used as an grade of 43 observed with IS12269, conform with ordinary Portland cement which is commercially available. 
Specific gravity and initial setting time of the cement were 3.13 and 25minutes. Silica fume has one of the good mechanical properties and microstructure of the concrete admixtures of normal cement concrete. In this study replacement of binder materials value of $5 \%, 10 \%$, and $15 \%$ was observed.

\section{B. Fine Aggregate}

River sand was used as fine aggregate which possess water absorption of $0.5 \%$ and specific gravity of 2.63. Manufactured sand is procured from hard granite stone by crushing. It was used in some quantity replacement of sand in concrete. Physical properties of $\mathrm{M}$ sand and sand are presentenced in table I. fabricated sand particles are precise fit as a fiddle and their unpleasant surface improves the inner erosion in the blend. As a result of that the low water absorption is not affected workability properties.

TABLE I. Physical Properties of Sand And M Sand

\begin{tabular}{|c|l|l|l|}
\hline S.No & \multicolumn{1}{|c|}{ Property } & \multicolumn{1}{c|}{ Sand } & \multicolumn{1}{c|}{ M-Sand } \\
\hline 1 & Specific Gravity & 2.63 & 2.73 \\
\hline 2 & Water Absorption & $1.52 \%$ & $0.6 \%$ \\
\hline 3 & Fineness Modulus & 2.65 & 3.4 \\
\hline 4 & Surface Texture & Smooth & Rough \\
\hline 5 & Particle Shape & Rounded & Angular \\
\hline
\end{tabular}

\section{Coarse Aggregate}

Coarse Aggregate was used with a maximum size of $12.5 \mathrm{~mm}$ and down size of 4.75 . The size and shape of the aggregate particles determine the quantity of cement involve in the mix. The physical properties of coarse aggregate was investigated and presented in table II.

TABLE II. Physical Properties of Coarse Aggregate

\begin{tabular}{|c|l|l|}
\hline S.No & \multicolumn{1}{|c|}{ Property } & Coarse Aggregate \\
\hline 1 & Specific Gravity & 2.8 \\
\hline 2 & Water Absorption & $0.65 \%$ \\
\hline 3 & Fineness Modulus & 9.4 \\
\hline 4 & Crushing Value & 17.5 \\
\hline 5 & Impact Value & 12.5 \\
\hline
\end{tabular}

\section{Resin}

In the creation of polymer concrete, unsaturated polyester gum cover material was utilized. Polyester tar was chosen because of its high more prominent mechanical and concoction attributes and was progressively sensible contrasted with epoxy gum just as its preferences, for example, broad business comfort in the development of polymer concrete. Polyester resin consists of specific weight 1.13 and vapor density heavier than air.

\section{E. Hardener and accelerator}

In the production of polymer concrete, materials beginning (solidifying) and quickening concoction response are utilized. Hardener is a substance that starts the synthetic response by causing sap and monomer solidifying to tie-connecting. Most ordinarily utilized peroxide impetus is methyl ethyl ketone peroxide. Most normally utilized quickening agent is cobalt. Hardener and accelerator density was $1.16 \mathrm{~g} / \mathrm{cm}^{3}$ and $0.98 \mathrm{~g} / \mathrm{cm}^{3}$

\section{CONCRETE MIX PROPORTIONS}

Concrete variables were divided into two major types. The first type of Normal Ordinary Portland Cement concrete (OPC) mixture were divided into four groups, the main replacement of $\mathrm{M}$-sand $80 \%$ replacement with natural river sand and silica fume replacement percentage which is $0 \%, 5 \%, 10 \%$ and $15 \%$. The mix proportion for M30 grade Normal Ordinary Portland Cement concrete is shown in table III

The second type of polymer concrete mixture was selected to investigate the effects of the silica fume shown in table IV [7] . Polymer concrete was produced by replacing M-sand with silica fume in the rates of $0 \%, 5 \%$, and $10 \%$ and then investigated. First should weigh or measure the materials (M sand, silica fume, polyester resin, MEKP, cobalt).Then mix the polyester resin and hardener (MEKP) are together in a glass container with a spatula. Now add this mixer to the M-sand and the filler material silica fume [8] which have measured and kept in the mixing pan and mix the mixer nicely without any lumps after mixing the hardener MEKP and accelerator cobalt together in a glass container, then add this to the mixer and mix it well without any lumps.

TABLE III. Mix Proportion for Normal Ordinary Portland Cement Concrete

\begin{tabular}{|c|c|c|c|c|c|c|}
\hline $\begin{array}{c}\text { Mix } \\
\text { Id }\end{array}$ & $\begin{array}{c}\text { Cement } \\
\mathrm{kg} / \mathrm{m}^{3}\end{array}$ & $\begin{array}{l}\text { Silica } \\
\text { fume } \\
\mathrm{kg} / \mathrm{m}^{3}\end{array}$ & $\begin{array}{l}\text { Sand } \\
\mathrm{kg} / \mathrm{m}^{3}\end{array}$ & $\begin{array}{c}\text { M } \\
\text { Sand } \\
\mathrm{kg} / \mathrm{m}^{3} \\
\end{array}$ & $\begin{array}{c}\text { Coarse } \\
\text { Aggregate } \\
\mathbf{k g} / \mathrm{m}^{3} \\
\end{array}$ & $\begin{array}{l}\text { Water } \\
\mathrm{kg} / \mathrm{m}^{3}\end{array}$ \\
\hline CS-1 & 450 & 0 & 496 & 124 & 1157 & 192 \\
\hline CS-2 & 427.5 & 22.5 & 496 & 124 & 1157 & 192 \\
\hline CS-3 & 405 & 45 & 496 & 124 & 1157 & 192 \\
\hline CS-4 & 382.5 & 67.5 & 496 & 124 & 1157 & 192 \\
\hline
\end{tabular}

TABLE IV. Mix Proportion for Polymer Concrete

\begin{tabular}{|c|c|c|c|c|c|}
\hline Mix Id & Resin & Hardner & Accelerator & $\begin{array}{c}\text { M } \\
\text { Sand }\end{array}$ & $\begin{array}{c}\text { Silica } \\
\text { Fume }\end{array}$ \\
\hline PC-1 & $40 \%$ & $1.5 \%$ & $0.5 \%$ & $58 \%$ & 0 \\
\hline PC-2 & $40 \%$ & $1.5 \%$ & $0.5 \%$ & $53 \%$ & $5 \%$ \\
\hline PC-3 & $40 \%$ & $1.5 \%$ & $0.5 \%$ & $48 \%$ & $10 \%$ \\
\hline
\end{tabular}

\section{RESULT AND DISCUSSION}

In the experiments results were divided into two main groups. In the first group experiments, investigation between various proportion of silica fume with $\mathrm{M}$ sand its compressive strength, spilt tensile and flexural strength were noted. In the second group experiments polymer concrete was produced with various proportion of silica fume and to investigate the mechanical properties of polymer concrete. 


\section{A. Compressive Strength}

Figure. 1 demonstrates the compressive strength of 7 and 28 days bond cement was $24.9 \mathrm{~N} / \mathrm{mm}^{2}$ and $33.6 \mathrm{~N} / \mathrm{mm}^{2}$, by substitution of $80 \%$ of M-sand the compressive strength is $30.57 \mathrm{~N} / \mathrm{mm}^{2}$. When looking at the compressive strength of was diminished for substitution of $\mathrm{M}$ sand concrete. Its demonstrates that include silica fume in fluctuating rate to build the quality of $\mathrm{M}$ sand concrete.5\% silica fume supplanting with $\mathrm{M}$ sand compressive strength is 33.05 $\mathrm{N} / \mathrm{mm}^{2}, 10 \%$ of substitution of silica fume with $M$ sand compressive strength is $36.04 \mathrm{~N} / \mathrm{mm}^{2}$ and $15 \%$ supplanting of silica smolder with $\mathrm{M}$ sand compressive strength is 28.05 $\mathrm{N} / \mathrm{mm}^{2}$. At the point when contrasted with $5 \%$ and $10 \%$ the strength was expanded due to pozzolanic response with silica fume. At the point when thought about $10 \%$ and $15 \%$ the strength is diminished on the grounds that the more fineness of silica fume substance diminishes the strength of concrete.

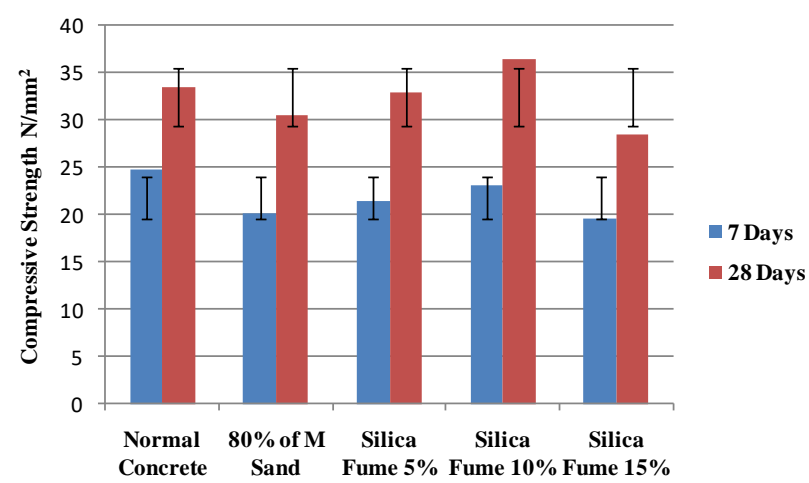

Fig. 1. Compressive Strength of Normal Concrete

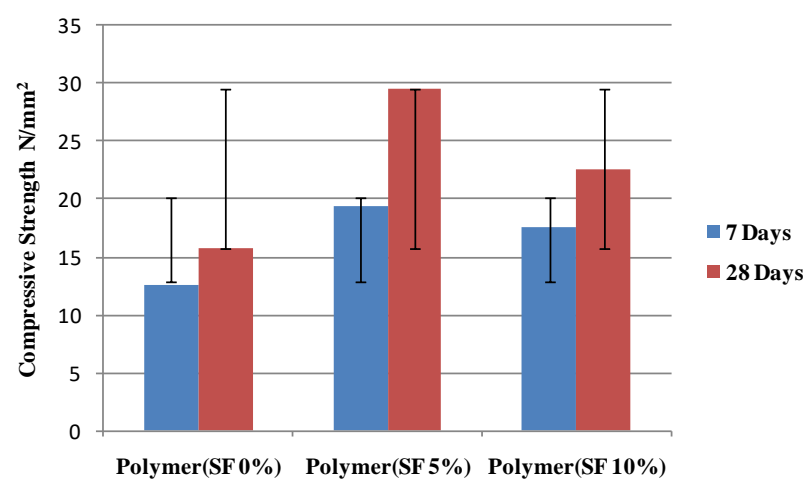

Fig. 2. Compressive Strength of Polymer Concrete

Figure. 2 shows the 28 days compressive strength for polymer concrete with SF $0 \%$ is $15 \mathrm{~N} / \mathrm{mm}^{2}$, polymer concrete with SF $5 \%$ is $30 \mathrm{~N} / \mathrm{mm}^{2}$ and $15 \%$ polymer concrete with SF concrete the 5\% strength is increased. When compared $5 \%$ and $10 \%$ polymer concrete the $10 \%$ strength is decreased. The result shows that highest compressive strength was obtained at $5 \%$ polymer concrete with silica fume.

\section{B. Split Tensile Strength}

Figure. 3 demonstrates the 28 days split tensile for ordinary cement is $3.2 \mathrm{~N} / \mathrm{mm}^{2}$, by substitution of $80 \%$ of M-sand the split tensile is $3.0 \mathrm{~N} / \mathrm{mm}^{2}$. When differentiating the split typical concrete and $80 \%$ substitution of M-sand, the quality $10 \%$ is $23 \mathrm{~N} / \mathrm{mm}^{2}$.when compared $0 \%$ and $5 \%$ polymer

tensile of ordinary cement and 80 percent M-sand substitution, the quality was decreased to supplant M-sand cement and silica exhaust were acquainted with increment the quality of M-sand concrete in various rates. $5 \%$ of supplanting of silica smolder with $\mathrm{M}$ sand, the elasticity is $3.6 \mathrm{~N} / \mathrm{mm}^{2}$, $10 \%$ of supplanting of silica seethe with $\mathrm{M}$ sand, the rigidity is $3.8 \mathrm{~N} / \mathrm{mm} 2$ and $15 \%$ supplanting of silica fume with $\mathrm{M}$ sand tensile is $3.2 \mathrm{~N} / \mathrm{mm}^{2}$.when contrasted with $5 \%$ and $10 \%$ the quality was expanded. At the point when thought about $10 \%$ and $15 \%$ the quality is diminished in light of the fact that the more fineness of silica fume substance diminishes the quality of cement. The most noteworthy split tensile was accomplished in $10 \%$ supplanting of silica fume with $\mathrm{M}$ sand

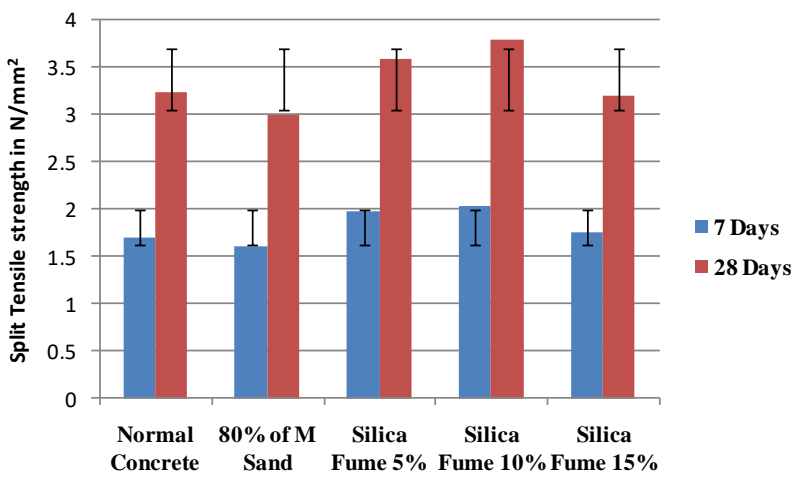

Fig. 3.Split Tensile of Normal Concrete

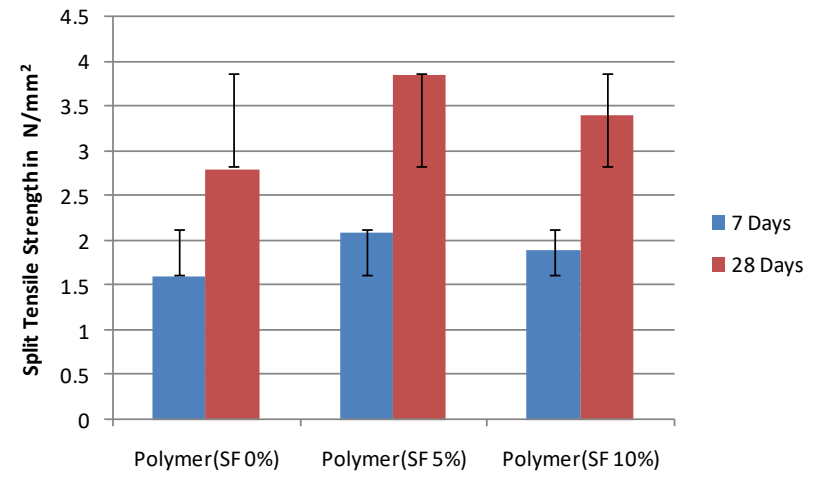

Fig. 4.Split Tensile Srength of Polymer Concrete

Figure.4 shows the 28 days split tensile strength for polymer concrete by using M-sand is $2.8 \mathrm{~N} / \mathrm{mm}^{2}$. When compared add silica fume in varying percentage to increase the tensile strength of polymer concrete using $\mathrm{M}$ sand concrete. When compared $10 \%$ and $15 \%$ the strength is decreased because the more fineness of silica fume content decreases the split tensile strength. The maximum split tensile strength was attained in $10 \%$ replacement of silica fume with M sand.

\section{Flexural Strength}

Figure. 5 shows the 28 days Flexural strength for $10 \%$ of replacement of silica fume was maximum compare with other mix proportion with $\mathrm{M}$ silica fume and $15 \%$ replacement of silica fume with M-sand flexural strength is $8.8 \mathrm{~N} / \mathrm{mm}^{2}$.when compared to $5 \%$ and $10 \%$ the strength was increased. 
When compared $10 \%$ and $15 \%$ the strength is decreased because the more fineness of silica fume content decreases the strength of concrete.

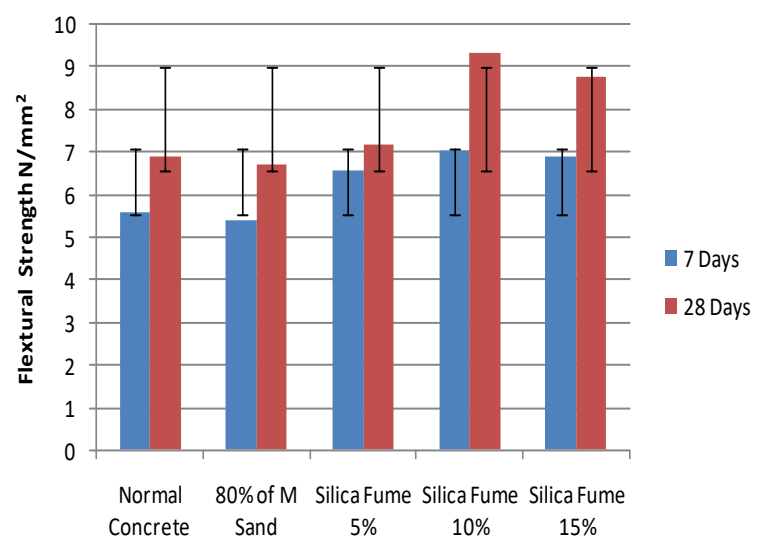

Fig. 5. Flexural Srength of Normal Concrete

\section{CONCLUSION}

The following conclusion can be drawn.

\section{A. Normal Concrete using M-Sand}

In this study compared normal concrete and replacement of silica fume with M-sand. The result shows that replacement of silica fume in varying proportions $(5 \%, 10 \%$ and $15 \%)$ for increasing the strength the M-sand concrete.

- The compressive strength of normal concrete using M-sand increased with silica fume replacement of cement up to $10 \%$. At the point when thought about $10 \%$ and $15 \%$ the strength is decreased in light of the fact that the more fineness of silica fume substance reduces the quality of concrete.

- The 28 days tensile strength for normal concrete was $3.2 \mathrm{~N} / \mathrm{mm} 2$, by replacement of $80 \%$ of M-sand the split tensile strength was $3.0 \mathrm{~N} / \mathrm{mm} 2$. When comparing the split tensile strength of normal concrete and $80 \%$ replacement of M-sand, the strength was decreased by $3.03 \%$ compared to normal concrete.

- When compared $10 \%$ and $15 \%$ the strength of the concrete decreased because of the more fineness of silica fume content. The maximum split tensile strength was attained from $10 \%$ silica fume replacement with $\mathrm{M}$ sand.

- The flexural strength result for both 7 and 28 days were same. When comparing the flexural strength of $5 \%$ and $10 \%$. The $10 \%$ strength was increased. When compared $10 \%$ and $15 \%$, the $15 \%$ strength is decreased.

\section{B. Polymer Concrete using M-sand}

In stage two we compared the polymer concrete with and without the silica fume. Polymer concrete is improving the mechanical properties Polymer concrete is improving the mechanical properties.

- Polymer solid framework mostly with a mean to fill the small scale voids. In 7 days test results highest strength $\mathrm{PC}$ was attained at $5 \% \mathrm{SF}$ in polymer concrete. But PC with $10 \% \mathrm{SF}$ strength is reduced by $2.2 \%$.
- In 28 days test results the highest strength PC was attained at 5\% SF in Polymer concrete. But PC with $10 \%$ SF strength was reduced by $7 \%$.

- When compared 7 and 28 days test results the maximum compressive strength and split tensile strength was attained at $5 \%$. The strength was reduced in $10 \%$.Because higher replacement of silica fume gives lower strength.

\section{ACKNOWLEDGMENT}

The authors would like to place their gratitude to the Kalasalingam Academy of Research and Education students P.Santhini Prabha and K.Subha Meenu of B.Tech. Civil Engineering for their help in casting and testing of the polymer concrete.

\section{REFERENCES}

1. H Temiz, A.Y Karakeci, "An investigation on microstructure of cement paste containing fly ash and silica fume," Cement and Concrete Research, vol. 32, pp. 1131-1132, Julyl 2002.

2. Praveen Kumar K, "Strength and Workability of Cement Mortar With Manufactured Sand," International Journal of Research in Engineering and Technology, vol. 04, pp. 186-189, Feb 2015

3. Mehran Khan, Majid Ali, "Improvement in concrete behavior with fly ash, silica-fume and coconut fibres," Construction and Building Materials, vol.203, pp. 174-187, April 2019

4. Thanongsak Nochaiya, Watcharapong Wongkeo, Arnon Chaipanich, "Utilization of fly ash with silica fume and properties of Portland cement-fly ash-silica fume concrete," Fuel, vol. 89, pp. 768-774, March 2010

5. Garas, V. Y., and Vipulanandan, C. Review of polyseter polymer concreteproperties, Univ. of Houston, Houston, 2003.

6. Mehmet Saribiyik, Abdullah Piskin, Ali Saribiyik, "The effects of waste glass powder usage on polymer concrete" Construction and Building Materials, vol.47, pp. 840-844, June 2013

7. Raman Bedi, Rakesh Chandra and S.P. Singh, "Reviewing some properties of polymer concrete, "Indian Concrete Journal, vol.88, pp. 47-68, August 2014

8. Barbut M, Harja M, Baran I,"Comparison of mechanical properties for polymer concrete with different types of filler," Journal of Materials in Civil Engineering, vol 22, pp. 696-701, July 2010

\section{AUTHORS PROFILE}

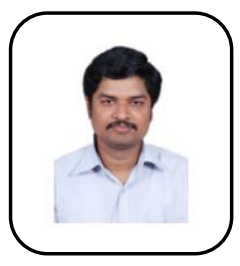

R.Premkumar had completed B.E degree in Civil Engineering and M.E degree in Structural Engineering from Anna University, Chennai, Tamil Nadu in 2008 and 2012 respectively. He is currently working as Assistant Professor in the department of Civil Engineering at Kalasalingam Academy of Research and Education. He has 2 year of industrial experience and 7 years experience in academics and consultancy. His current research interests are Geopolymer Concrete and Earthquake resistance structures.

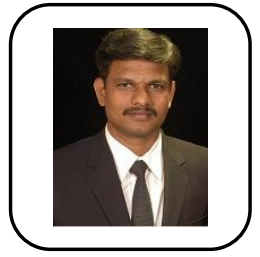

Ramesh Babu Chokkalingam completed his Ph.D. from IIT Chennai. He has more than ten years of experience in teaching and research. His areas of research includes pervious concrete, geopolymer concrete, and high volume flyash concrete. 


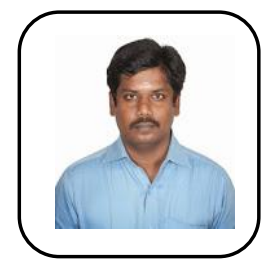

Dr M.Shanmugasundaram: He had completed his B.E degree in Civil Engineering from RCET Madurai, M.E in Structural Engineering, TCE Madurai. He completed his Ph.D in 2014 under the esteemed guidance of Dr. K.Sudalaimani, Professor, TCE, Madurai. He has 30+ international research publications to his credits. He had filed three patents. He has 3 years of industrial experience and 10 years of teaching experience. His recent research interests include, sustainable materials and polymer concrete.

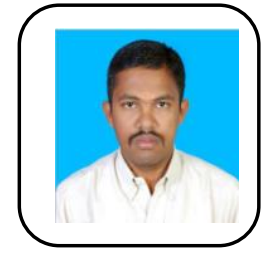

Er.S.Rajesh Completed B.E (Civil) degree from GCE, Tirunelveli in 2009 and M.E (Environmental) degree from ACCET,Karakudi in 2013. He is working as Asst professor in KARE , Krishnankoil and Research scholar in KARE.His research area is Envionmental Engineerring..He is having 7 years Academic Experience and 10 years Industry consultancy Experience. He is Chartered Engineer \& Valuer in India. He is Professional member of the IOV, IEI and PE. He has published more than 10 SCOPUS indexed Journal and Conference in and around India. 